\title{
STVARALAŠTVO HRVATSKIH SKLADATELJICA U UDŽBENICIMA GLAZBENE KULTURE
}

\author{
Marijo Krnić ${ }^{1}$, Ani Silić \\ ${ }^{1}$ Filozofski fakultet, Sveučilište u Splitu, Hrvatska \\ mkrnic@ffst.hr; asilic@ffst.hr
}

Primljeno: 25. 1. 2021.

\begin{abstract}
Glazbena djela skladateljica važan su, ali nedovoljno obrađen segment glazbeno-povijesne baštine te u nedovoljnoj mjeri zastupljen element suvremene glazbene kulture. Djeca se s djelima skladateljica u prvom redu upoznaju u okviru osnovnoškolske nastave glazbe. U radu je prikazano istraživanje kojemu je cilj bio utvrditi zastupljenost djela skladateljica namijenjenih za slušanje i pjevanje u udžbenicima za Glazbenu kulturu koji su u uporabi u Hrvatskoj, a posebno djela hrvatskih skladateljica. U istraživanju je analiziran 21 udžbenik triju hrvatskih nakladničkih kuća. Rezultati ukazuju na to da su u udžbenicima najviše zastupljena djela skladatelja, potom tradicijske skladbe, dok su djela skladateljica zastupljena u bitno manjoj mjeri. Autori predlažu revidiranje popisa djela za slušanje $i$ pjevanje u udžbenicima za Glazbenu kulturu kako bi se u njih u većoj mjeri uvrstilo stvaralaštvo domaćih i stranih skladateljica.
\end{abstract}

Ključne riječi: skladateljice, Glazbena kultura, udžbenici, skladbe za pjevanje i slušanje

\section{Uvod}

Sve do 20. stoljeća umjetnička je glazba sfera kreativnoga čovjekova djelovanja u kojoj primat, a u pojedinim glazbeno-povijesnim razdobljima i ekskluzivitet, imaju muškarci. Žene koje su ostale zapamćene u povijesti glazbe mahom su se ostvarile kao reproduktivne

${ }^{1}$ Rad pod naslovom Stvaralaštvo hrvatskih skladateljica u nastavi Glazbene kulture u osnovnoj školi diplomska je radnja obranjena 2020. godine na Filozofskom fakultetu Sveučilišta u Splitu, na Odsjeku za učiteljski studij, pod mentorstvom mr. sc. Marija Krnića. 
umjetnice jer se - i onda kada je ženama bilo dopušteno da se ostvare izvan uloga supruge, majke i domaćice - smatralo da one nemaju kreativni kapacitet za skladateljski rad. Kao neke od razloga zašto se žene do 20. stoljeća nisu više bavile skladanjem Reitsma $(2014,3)$ ističe onovremeni stav da su žensko tijelo i um slabiji od muškarčeva pa žene u odnosu na muškarca imaju niže sposobnosti te stav da je jedini prihvatljiv način bavljenja glazbom za žene bio podržavanje suprugove glazbene aktivnosti. O odnosu prema ženama kao umjetnicama zorno svjedoči komentar pijaniste, dirigenta i skladatelja Hansa von Bülowa (1830-1894):

»Reproduktivna genijalnost može biti priznata ljepšem spolu, ali produktivna nipošto. Nikada neće postojati skladateljice... Ne vjerujem u ženski oblik riječi 'kreator'. « (Gates, 2006, 1)

Zbog patrijarhalnih društvenih normi ženama je bio značajno ograničen pristup obrazovanju u području skladanja sve do 20. stoljeća (Green, 1997, 88). Uz nedostatak adekvatnoga obrazovanja, ženama je za bavljenje skladateljskim radom nedostajala i financijska potpora te pozitivan poticaj, odnosno ohrabrenje (Ammer, 2001, 92). Važno je istaknuti da je sve do poslije Drugoga svjetskoga rata (kada je krenula ponovna kampanja opismenjavanja) veliki dio populacije (na području bivše Jugoslavije, ali i drugdje) bio nepismen, a najbrojnija kategorija među njima bile su upravo žene (Senjan, 2021, 100). Stoga su se glazbom mogle baviti samo žene iz srednjega staleža ili iz aristokratskih krugova.

Žene koje su se odvažile stvarati glazbu i kojima su to životne okolnosti dopuštale, često su morale svoja djela objavljivati pod bratovim ili suprugovim imenom kako bi ona uopće izašla u javnost. Zahvaljujući naporima suvremene muzikologije danas su nam ipak poznata imena i stvaralaštvo skladateljica ranijih glazbeno-povijesnih epoha, poput Hildegard von Bingen, Barbare Strozzi, Clare Schumann, Fanny Mendelssohn, Ethel Smyth, Ruth Crawford Seeger i mnogih drugih. Jednako tako, poznat nam je i umjetnički rad hrvatskih skladateljica, kako onih koje su djelovale do kraja 20. stoljeća - Elene Pucić-Sorkočević (prve poznate hrvatske skladateljice), Dore Pejačević i Ivane Lang, tako i onih koje i danas stvaraju - Đeni Dekleve Radaković, Sanje Drakulić, Olje Jelaska, Sande Majurec, Viktorije Čop, Mirele Ivičević, Ane Horvat, Sare Glojnarić i drugih. 
No, djela skladateljica, prije svega onih koje su djelovale do 20. stoljeća, rijetko pronalazimo u javnom prostoru, bilo na koncertnim programima, različitim medijskim platformama ili kao predmet interesa znanstvene i stručne javnosti. Njihove biografije i njihovo stvaralaštvo poznati su samo malobrojnim usko specijaliziranim znanstvenicima ili rijetkim strastvenim poklonicima njihova umjetničkoga rada.

\section{Pregled dosadašnjih istraživanja}

Prvi susret djeteta s glazbenom umjetnošću, pa tako i s djelima skladateljica, trebao bi biti obiteljski dom. Međutim, rezultati istraživanja ukazuju na to da roditelji nedovoljno vremena provode s djecom u glazbenim aktivnostima. Krnić i Kodžoman-Radan $(2015,59)$ utvrdili su da $37,5 \%$ roditelja djece vrtićke dobi provede dnevno prosječno manje od pola sata vremena s djecom u različitim oblicima glazbenih aktivnosti.

Važnost ranoga kontakta s glazbom različitih stilskih obilježja od iznimnoga je značaja s obzirom na to da su brojna istraživanja utvrdila da su mlađa djeca otvorenija prema različitim glazbama i da se otvorenost smanjuje ulaskom u adolescenciju (Dobrota i Ćurković, 2006, 111; Dobrota i Mikelić, 2012, 143; Dobrota i Topić, 2018, 203; LeBlanc et al., 1996, 58). U tom smislu značajnu ulogu imaju predškolske i osnovnoškolske ustanove u kojima se provodi institucionalizirani glazbeni odgoj djece. No, uloga škole, odnosno nastave Glazbene kulture u kreiranju glazbenih preferencija kao temelja za kreiranje dugoročnih sviđanja određene glazbe, također je snažnija u ranijoj dobi kada učenici iskazuju pozitivnije stavove prema nastavi glazbe (Dobrota i Conar, 2018, 136; Šulentić Begić, Begić i Pušić, 2020, 195). Iz tih je razloga od iznimne važnosti djecu predškolskoga i ranoga školskoga uzrasta među ostalim izlagati značajnim djelima domaćih i stranih skladateljica kako bismo stvorili pretpostavke za razvijanje preferencija prema njihovu stvaralaštvu. Višekratna izlaganja takvim glazbenim sadržajima povećat će i poznatost takve glazbe, što je ponovno u pozitivnoj korelaciji s glazbenim preferencijama (Carper, 2001).

Planiranje i programiranje nastavnoga procesa danas se najčešće temelji na udžbenicima i metodičkim materijalima uz udžbenike. Stoga je od iznimnoga značaja uskladiti udžbenike sa zahtjevima politi- 
ke rodno osjetljivoga obrazovanja. Kvantitativne i kvalitativne analize sadržaja udžbenika iz rodne perspektive ukazuju na to da udžbenici u nedovoljnoj mjeri promiču ravnopravnost spolova, kako u nastavi glazbe (Bernabé-Villodre i Martínez-Bello, 2018, 507; Green, 1997, 230; Lindeman, 1992, 57; Zaimont, 1987, 465), tako i u ostalim nastavnim područjima (Janušić, 2008, 79; Knežević, 2012, 91; Trupković, 2008, 190).

\section{Istraživanje: Stvaralaštvo skladateljica u udžbenicima za Glazbenu kulturu}

Budući da su udžbenici i prateći materijali uz udžbenike najčešće osnova za planiranje i realizaciju nastave Glazbene kulture, istraživanjem se htjelo ustanoviti jesu li i u kojoj mjeri u tim nastavnim sredstvima zastupljena djela skladateljica.

Cilj istraživanja bio je utvrditi zastupljenost djela za slušanje i pjevanje skladateljica u udžbenicima za Glazbenu kulturu u osnovnoj školi. Na temelju cilja istraživanja postavljeni su sljedeći zadatci:

1. Utvrditi broj i udio skladbi za pjevanje i slušanje skladateljica u udžbenicima za Glazbenu kulturu.

2. Utvrditi broj i udio skladbi za pjevanje i slušanje hrvatskih skladateljica u udžbenicima za Glazbenu kulturu.

3. Usporediti broj skladbi za pjevanje i slušanje skladateljica u udžbenicima za Glazbenu kulturu s obzirom na razred.

4. Usporediti broj skladbi za pjevanje i slušanje hrvatskih skladateljica u udžbenicima za Glazbenu kulturu s obzirom na razred.

U istraživanju je načinjena analiza udžbenika za Glazbenu kulturu u osnovnoj školi. Analizom je obuhvaćen ukupno 21 udžbenik za Glazbenu kulturu od prvoga do osmoga razreda osnovne škole u Republici Hrvatskoj. Analizirani su sljedeći udžbenici: Glazbeni krug 1, Glazbeni krug 2 i Glazbeni krug 3 (nakladnik Profil Klett); Moja glazba 1, Moja glazba 2 i Moja glazba 3 (nakladnik Alfa); Razigrani zvuci 1, Razigrani zvuci 2 i Razigrani zvuci 3 (nakladnik Školska knjiga); Allegro 4, Allegro 5, Allegro 6, Allegro 7 i Allegro 8 (nakladnik Školska knjiga), Svijet glazbe 4, Svijet glazbe 5, Svijet glazbe 6 i Svijet glazbe 7 (nakladnik Alfa) te Glazbena petica, Glazbena šestica i Glazbena osmica (naklad- 
nik Profil Klett). Udžbenici Glazbena četvrtica, Glazbena sedmica i Svijet glazbe 8 nisu bili dostupni u vrijeme provođenja istraživanja.

Udžbenici Razigrani zvuci 1, Razigrani zvuci 2 i Razigrani zvuci 3, Moja glazba 1, Moja glazba 2 i Moja glazba 3, Glazbeni krug 1, Glazbeni krug 2 i Glazbeni krug 3 te Allegro 5, Allegro 6 i Allegro 7 izdani su 2020. godine. Udžbenici Svijet glazbe 5, Svijet glazbe 6, Svijet glazbe 7 te Glazbena osmica izdani su 2019. godine, a udžbenik Svijet glazbe 4 2018. godine. Udžbenici Allegro 4 i Allegro 8 izdani su 2014. godine, Glazbena šestica 2013. godine, a Glazbena petica izdana je 2012. godine.

Prilikom analize popisane su u svakome udžbeniku sve skladbe za slušanje i pjevanje te njihovi autori. Skladbe su potom razvrstane prema razredu te prema kriteriju autorstva i to u sljedeće kategorije: skladbe skladatelja, skladbe skladateljica, tradicijske skladbe i ostale skladbe (didaktički primjeri, skladbe nastale kao rezultat suradnje skladatelja i skladateljice, skladbe nepoznatoga autora ili porijekla). Nakon razvrstavanja skladbi po navedenim kategorijama pristupilo se uspoređivanju broja skladbi prema razredu i autorstvu.

\subsection{Rezultati analize}

U ovome su potpoglavlju prikazani rezultati analize skladbi za slušanje i pjevanje u udžbenicima za Glazbenu kulturu u osnovnoj školi po razredima osnovne škole.

\subsubsection{Skladbe za slušanje i pjevanje u udžbenicima za Glazbenu kulturu u prvom razredu}

Analizom su bili obuhvaćeni sljedeći udžbenici za Glazbenu kulturu u prvom razredu osnovne škole: Moja glazba 1 (nakladnik Alfa), Glazbeni krug 1 (nakladnik Profil Klett) i Razigrani zvuci 1 (nakladnik Školska knjiga). U udžbenicima je ukupno 135 skladbi, od čega 71 skladba za pjevanje te 64 skladbe za slušanje. Od 71 skladbe za pjevanje, 28 skladbi su djela skladatelja, 11 skladbi skladateljica, 27 tradicijskih skladbi i pet ostalih skladbi. Od 64 skladbe za slušanje, 57 skladbi su djela skladatelja, dvije skladbe skladateljica i pet tradicijskih skladbi (Tablica 1). 
Tablica 1. Skladbe za pjevanje i slušanje u udžbenicima za prvi razred

\begin{tabular}{|c|c|c|c|c|c|}
\hline 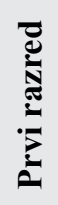 & 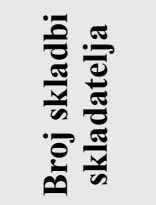 & 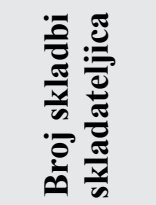 & 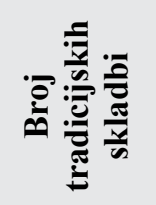 & 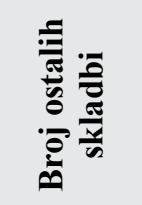 & 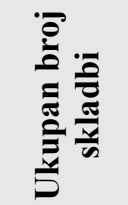 \\
\hline & $\begin{array}{c}28 \\
(39,44 \%)\end{array}$ & $\begin{array}{c}11 \\
(15,49 \%)\end{array}$ & $\begin{array}{c}27 \\
(38,03 \%)\end{array}$ & $\begin{array}{c}5 \\
(7,04 \%)\end{array}$ & $\begin{array}{c}71 \\
(100 \%)\end{array}$ \\
\hline 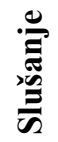 & $\begin{array}{c}57 \\
(89,06 \%)\end{array}$ & $\begin{array}{c}2 \\
(3,13 \%)\end{array}$ & $\begin{array}{c}5 \\
(7,81 \%)\end{array}$ & $\begin{array}{c}0 \\
(0,00 \%)\end{array}$ & $\begin{array}{c}64 \\
(100 \%)\end{array}$ \\
\hline
\end{tabular}

U udžbenicima za prvi razred ukupno je 13 (9,63 \%) skladbi skladateljica. Od toga je 11 skladbi hrvatskih skladateljica. U udžbenicima su zastupljena djela sljedećih hrvatskih autorica: Marije Matanović, Ljiljane Goran, s. Lujze Kozinović, Doris Kovačić, Štefice Đuričić i Dore Pejačević.

\subsubsection{Skladbe za slušanje i pjevanje u udžbenicima za Glazbenu kulturu u drugom razredu}

Analizom su bili obuhvaćeni sljedeći udžbenici za Glazbenu kulturu u drugom razredu osnovne škole: Moja glazba 2 (nakladnik Alfa), Glazbeni krug 2 (nakladnik Profil Klett) i Razigrani zvuci 2 (nakladnik Školska knjiga). U udžbenicima je ukupno 173 skladbi, od čega 84 skladbe za pjevanje i 89 skladbi za slušanje. Od 84 skladbe za pjevanje, 23 skladbe su djela skladatelja, 14 je skladbi skladateljica, 39 je tradicijskih skladbi i osam ostalih skladbi. Od 89 skladbi za slušanje, 71 je skladba skladatelja, tri skladbe skladateljica, 14 tradicijskih skladbi i jedna skladba iz kategorije ostalih skladbi (Tablica 2). 
Tablica 2. Skladbe za pjevanje i slušanje u udžbenicima za drugi razred

\begin{tabular}{|c|c|c|c|c|c|}
\hline Dू. & 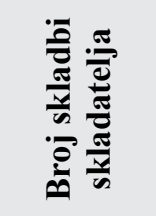 & 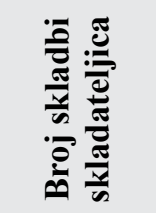 & 赵: & 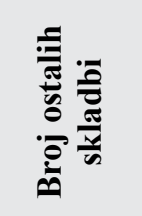 & 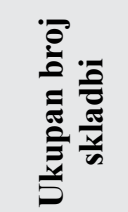 \\
\hline & $\begin{array}{c}23 \\
(27,38 \%)\end{array}$ & $\begin{array}{c}14 \\
(16,67 \%)\end{array}$ & $\begin{array}{c}39 \\
(46,43 \%)\end{array}$ & $\begin{array}{c}8 \\
(9,52 \%)\end{array}$ & $\begin{array}{c}84 \\
(100 \%)\end{array}$ \\
\hline 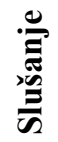 & $\begin{array}{c}71 \\
(79,78 \%)\end{array}$ & $\begin{array}{c}3 \\
(3,37 \%)\end{array}$ & $\begin{array}{c}14 \\
(15,73 \%)\end{array}$ & $\begin{array}{c}1 \\
(1,12 \%)\end{array}$ & $\begin{array}{c}89 \\
(100 \%)\end{array}$ \\
\hline
\end{tabular}

U udžbenicima za drugi razred ukupno je 17 (9,82 \%) skladbi skladateljica. Od toga je 14 skladbi hrvatskih skladateljica. Zastupljena su djela sljedećih hrvatskih skladateljica: Marije Matanović, Vesne Matanović Matić, Ane Janković, Mije Dimšić, Hede Piliš, Ljiljane Goran i s. Lujze Kozinović.

\subsubsection{Skladbe za slušanje i pjevanje u udžbenicima za Glazbenu kulturu u trećem razredu}

Analizom su bili obuhvaćeni sljedeći udžbenici za Glazbenu kulturu u trećem razredu osnovne škole: Moja glazba 3 (nakladnik Alfa), Glazbeni krug 3 (nakladnik Profil Klett) i Razigrani zvuci 3 (nakladnik Školska knjiga). U udžbenicima je ukupno 155 skladbi, od čega 64 skladbe za pjevanje i 91 skladba za slušanje. Od ukupno 64 skladbe za pjevanje, 25 skladbi su djela skladatelja, šest je skladbi skladateljica, 31 tradicijska skladba te dvije ostale skladbe. Od 91 skladbe za slušanje 76 je skladbi skladatelja, dvije skladbe skladateljica, 12 tradicijskih skladbi te jedna skladba u kategoriji ostalih skladbi (Tablica 3). 
Tablica 3. Skladbe za pjevanje i slušanje u udžbenicima za treći razred

\begin{tabular}{|c|c|c|c|c|c|}
\hline 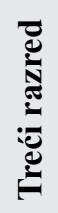 & 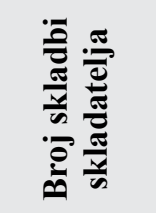 & 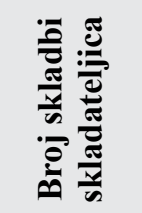 & 赵: & 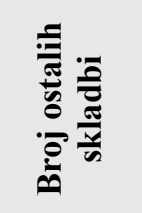 & 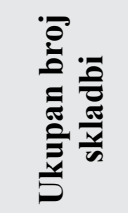 \\
\hline 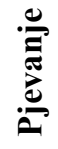 & $\begin{array}{c}25 \\
(39,06 \%)\end{array}$ & $\begin{array}{c}6 \\
(9,38 \%)\end{array}$ & $\begin{array}{c}31 \\
(48,44 \%)\end{array}$ & $\begin{array}{c}2 \\
(3,12 \%)\end{array}$ & $\begin{array}{c}64 \\
(100 \%)\end{array}$ \\
\hline 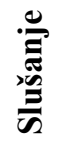 & $\begin{array}{c}76 \\
(83,51 \%)\end{array}$ & $\begin{array}{c}2 \\
(2,20 \%)\end{array}$ & $\begin{array}{c}12 \\
(13,19 \%)\end{array}$ & $\begin{array}{c}1 \\
(1,10 \%)\end{array}$ & $\begin{array}{c}91 \\
(100 \%)\end{array}$ \\
\hline
\end{tabular}

U udžbenicima za treći razred ukupno je osam (5,16 \%) skladbi skladateljica. Svih osam skladbi su djela hrvatskih skladateljica. Zastupljene su skladbe sljedećih hrvatskih autorica: Ane Janković, Maje Rogić, Dore Pejačević i Marije Matanović.

\subsubsection{Skladbe za slušanje i pjevanje u udžbenicima za Glazbenu kulturu u četvrtom razredu}

Analizom su bili obuhvaćeni sljedeći udžbenici za Glazbenu kulturu u četvrtom razredu osnovne škole: Svijet glazbe 4 (nakladnik Alfa) i Allegro 4 (nakladnik Školska knjiga). U udžbenicima je ukupno 133 skladbi, od čega 69 skladbi za pjevanje i 64 skladbe za slušanje. Od ukupno 69 skladbi za pjevanje, 36 je skladbi skladatelja, dvije skladbe skladateljica, 26 tradicijskih skladbi i pet ostalih skladbi. Od ukupno 64 skladbe za slušanje, 49 je skladbi skladatelja, 14 tradicijskih skladbi, jedna skladba iz kategorije ostalih skladbi, a djela skladateljica nisu zastupljena (Tablica 4). 
Tablica 4. Skladbe za pjevanje i slušanje u udžbenicima za četvrti razred

\begin{tabular}{|c|c|c|c|c|c|}
\hline Uू. & 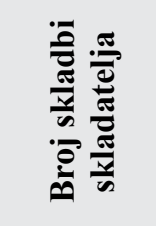 & 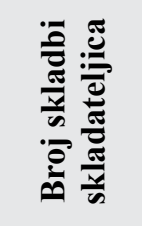 & 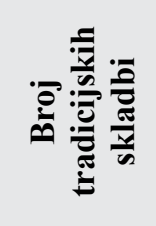 & 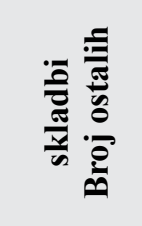 & 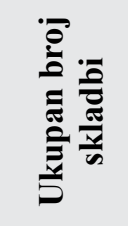 \\
\hline & $\begin{array}{c}36 \\
(52,17 \%)\end{array}$ & $\begin{array}{c}2 \\
(2,90 \%)\end{array}$ & $\begin{array}{c}26 \\
(37,68 \%)\end{array}$ & $\begin{array}{c}5 \\
(7,25 \%)\end{array}$ & $\begin{array}{c}69 \\
(100 \%)\end{array}$ \\
\hline 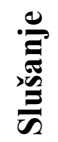 & $\begin{array}{c}49 \\
(76,56 \%)\end{array}$ & $\begin{array}{c}0 \\
(0,00 \%)\end{array}$ & $\begin{array}{c}14 \\
(21,88 \%)\end{array}$ & $\begin{array}{c}1 \\
(1,56 \%)\end{array}$ & $\begin{array}{c}64 \\
(100 \%)\end{array}$ \\
\hline
\end{tabular}

U udžbenicima za četvrti razred ukupno su dvije (1,5 \%) skladbe skladateljica. Obje skladbe su autorska djela hrvatskih skladateljica. To su skladbe Adele Dobrić Jelače i Marije Matanović.

\subsubsection{Skladbe za slušanje i pjevanje u udžbenicima za Glazbenu kulturu u petom razredu}

Analizom su bili obuhvaćeni sljedeći udžbenici za Glazbenu kulturu u petom razredu osnovne škole: Svijet glazbe 5 (nakladnik Alfa), Glazbena petica (nakladnik Profil Klett) i Allegro 5 (nakladnik Školska knjiga). U udžbenicima je ukupno 327 skladbi, od čega 100 skladbi za pjevanje i 227 skladbi za slušanje. Od ukupno 100 skladbi za pjevanje, 27 je skladbi skladatelja, tri skladbe skladateljica, 68 tradicijskih skladbi i dvije ostale skladbe. Od ukupno 227 skladbi za slušanje, 180 je skladbi skladatelja, tri skladbe skladateljica, 35 tradicijskih skladbi i devet ostalih skladbi (Tablica 5). 
Tablica 5. Skladbe za pjevanje i slušanje u udžbenicima za peti razred

\begin{tabular}{|c|c|c|c|c|c|}
\hline 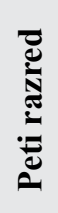 & 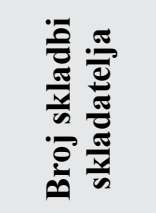 & 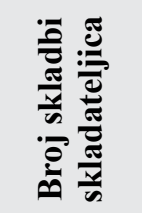 & 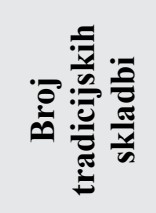 & 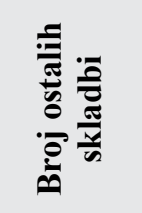 & 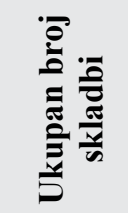 \\
\hline & $\begin{array}{c}27 \\
(27,00 \%)\end{array}$ & $\begin{array}{c}3 \\
(3,00 \%)\end{array}$ & $\begin{array}{c}68 \\
(68,00 \%)\end{array}$ & $\begin{array}{c}2 \\
(2,00 \%)\end{array}$ & $\begin{array}{c}100 \\
(100 \%)\end{array}$ \\
\hline 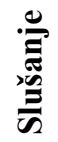 & $\begin{array}{c}180 \\
(79,30 \%)\end{array}$ & $\begin{array}{c}3 \\
(1,32 \%)\end{array}$ & $\begin{array}{c}35 \\
(15,42 \%)\end{array}$ & $\begin{array}{c}9 \\
(3,96 \%)\end{array}$ & $\begin{array}{c}227 \\
(100 \%)\end{array}$ \\
\hline
\end{tabular}

U udžbenicima za peti razred ukupno je šest (1,83 \%) skladbi skladateljica. Od toga su tri skladbe hrvatskih skladateljica. Zastupljena su djela sljedećih hrvatskih autorica: Anite Gregorić, Marije Matanović i Vesne Matana Matić.

\subsubsection{Skladbe za slušanje i pjevanje u udžbenicima za Glazbenu kulturu u šestom razredu}

Analizom su bili obuhvaćeni sljedeći udžbenici za Glazbenu kulturu u šestom razredu osnovne škole: Svijet glazbe 6 (nakladnik Alfa), Glazbena šestica (nakladnik Profil Klett) i Allegro 6 (nakladnik Školska knjiga). Udžbenici sadrže ukupno 403 skladbe, od čega 94 skladbe za pjevanje i 309 skladbi za slušanje. Od ukupno 94 skladbe za pjevanje, 36 je skladbi skladatelja, dvije skladbe skladateljica, 55 tradicijskih skladbi i jedna skladba u kategoriji ostalih skladbi. Od ukupno 309 skladbi za slušanje, 234 su skladbe skladatelja, šest skladbi skladateljica, 66 tradicijskih skladbi i tri skladbe u kategoriji ostalih skladbi (Tablica 6). 
Tablica 6. Skladbe za pjevanje i slušanje u udžbenicima za šesti razred

\begin{tabular}{|c|c|c|c|c|c|}
\hline 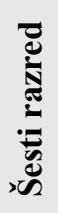 & 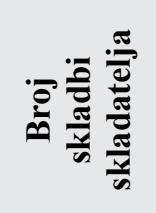 & 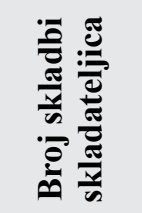 & 赵: & 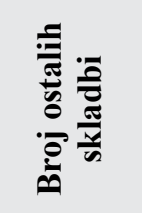 & 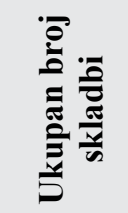 \\
\hline 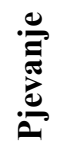 & $\begin{array}{c}36 \\
(38,30 \%)\end{array}$ & $\begin{array}{c}2 \\
(2,13 \%)\end{array}$ & $\begin{array}{c}55 \\
(58,51 \%)\end{array}$ & $\begin{array}{c}1 \\
(1,06 \%)\end{array}$ & $\begin{array}{c}94 \\
(100 \%)\end{array}$ \\
\hline 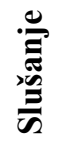 & $\begin{array}{c}234 \\
(75,73 \%)\end{array}$ & $\begin{array}{c}6 \\
(1,94 \%)\end{array}$ & $\begin{array}{c}66 \\
(21,36 \%)\end{array}$ & $\begin{array}{c}3 \\
(0,97 \%)\end{array}$ & $\begin{array}{c}309 \\
(100 \%)\end{array}$ \\
\hline
\end{tabular}

U udžbenicima za šesti razred ukupno je osam (1,99 \%) skladbi skladateljica. Od toga su dvije skladbe hrvatskih skladateljica. Zastupljena su djela sljedećih hrvatskih autorica: Andreje Gribl i Dore Pejačević.

\subsubsection{Skladbe za slušanje i pjevanje u udžbenicima za Glazbenu kulturu u sedmom razredu}

Analizom su bili obuhvaćeni sljedeći udžbenici za Glazbenu kulturu u sedmom razredu osnovne škole: Svijet glazbe 7 (nakladnik Alfa) i Allegro 7 (nakladnik Školska knjiga). Udžbenici sadrže ukupno 304 skladbe za pjevanje i slušanje, od čega je 59 skladbi za pjevanje i 245 skladbi za slušanje. Od ukupno 59 skladbi za pjevanje, 27 je skladbi skladatelja, dvije skladbe skladateljica i 30 tradicijskih skladbi. Od ukupno 245 skladbi za slušanje, 196 je skladbi skladatelja, dvije skladbe skladateljica, 40 tradicijskih skladbi i jedna skladba u kategoriji ostalih skladbi (Tablica 7). 
Tablica 7. Skladbe za pjevanje i slušanje u udžbenicima za sedmi razred

\begin{tabular}{|c|c|c|c|c|c|}
\hline 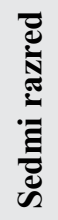 & 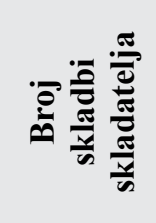 & 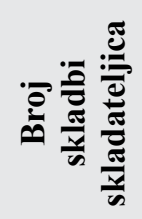 & 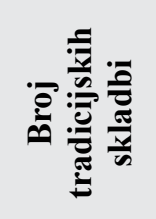 & 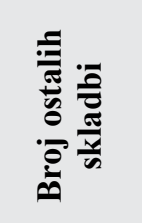 & 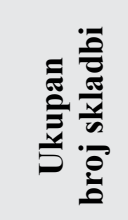 \\
\hline & $\begin{array}{c}27 \\
(45,76 \%)\end{array}$ & $\begin{array}{c}2 \\
(3,39 \%)\end{array}$ & $\begin{array}{c}30 \\
(50,85 \%)\end{array}$ & $\begin{array}{c}0 \\
(0,00 \%)\end{array}$ & $\begin{array}{c}59 \\
(100 \%)\end{array}$ \\
\hline 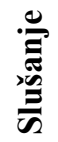 & $\begin{array}{c}196 \\
(80,00 \%)\end{array}$ & $\begin{array}{c}2 \\
(0,82 \%)\end{array}$ & $\begin{array}{c}46 \\
(18,77 \%)\end{array}$ & $\begin{array}{c}1 \\
(0,41 \%)\end{array}$ & $\begin{array}{c}245 \\
(100 \%)\end{array}$ \\
\hline
\end{tabular}

U udžbenicima za sedmi razred ukupno su četiri $(1,32 \%)$ skladbe skladateljica. Od toga su dvije skladbe hrvatskih skladateljica. Zastupljena su djela sljedećih hrvatskih autorica: Tamare Obrovac i Dore Pejačević.

\subsubsection{Skladbe za slušanje i pjevanje u udžbenicima za Glazbenu kulturu u osmom razredu}

Analizom su bili obuhvaćeni sljedeći udžbenici za Glazbenu kulturu u osmom razredu osnovne škole: Glazbena osmica (nakladnik Profil Klett) i Allegro 8 (nakladnik Školska knjiga). Udžbenici sadrže ukupno 246 skladbi za slušanje i pjevanje, od čega su 48 skladbe za pjevanje i 198 skladbi za slušanje. Od ukupno 48 skladbi za pjevanje, 31 je skladba skladatelja, jedna skladba skladateljice, 13 tradicijskih skladbi i tri ostale skladbe. Od ukupno 198 skladbi za slušanje, 181 je skladba skladatelja, 10 tradicijskih skladbi i sedam skladbi iz kategorije ostalih skladbi (Tablica 8). 
Tablica 8. Skladbe za pjevanje i slušanje skladbi u udžbenicima za osmi razred

\begin{tabular}{|c|c|c|c|c|c|}
\hline 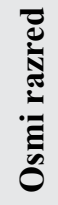 & 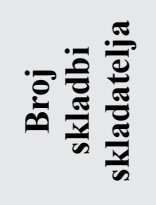 & 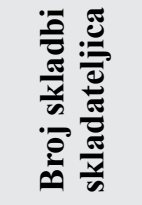 & 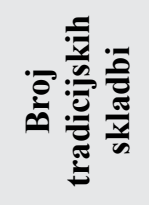 & 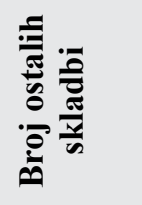 & 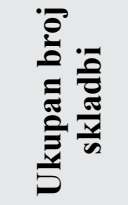 \\
\hline & $\begin{array}{c}31 \\
(64,59 \%)\end{array}$ & $\begin{array}{c}1 \\
(2,08 \%)\end{array}$ & $\begin{array}{c}13 \\
(27,08 \%)\end{array}$ & $\begin{array}{c}3 \\
(6,25 \%)\end{array}$ & $\begin{array}{c}48 \\
(100 \%)\end{array}$ \\
\hline 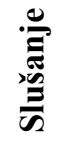 & $\begin{array}{c}181 \\
(91,41 \%)\end{array}$ & $\begin{array}{c}0 \\
(0,00 \%)\end{array}$ & $\begin{array}{c}10 \\
(5,05 \%)\end{array}$ & $\begin{array}{c}7 \\
(3,54 \%)\end{array}$ & $\begin{array}{c}198 \\
(100 \%)\end{array}$ \\
\hline
\end{tabular}

U udžbenicima za osmi razred samo je jedna skladba skladateljice. Skladba je djelo strane autorice.

\subsection{Rasprava}

Iz rezultata analize skladbi za slušanje i pjevanje u udžbenicima za Glazbenu kulturu u osnovnoj školi iščitavamo da je broj skladbi za slušanje i pjevanje koje su autorska djela skladateljica i njihov udio u ukupnom broju skladbi po razredu najveći u udžbenicima za prva dva razreda osnovne škole. Najveći udio skladbi skladateljica u ukupnom broju skladbi za slušanje i pjevanje je u udžbenicima za drugi razred $(9,83 \%)$, a najmanji u udžbenicima za osmi razred, gdje iznosi tek $0,41 \%$ ukupnoga broja skladbi za slušanje i pjevanje u osmom razredu. Podatci jasno ukazuju na to da su učenici tijekom svoga osnovnoškolskoga obrazovanja u kontaktu s izrazito malim brojem glazbenih djela čiji su autori skladateljice.

Osim broja i udjela skladbi skladateljica u ukupnome broju skladbi za slušanje i pjevanje, analizirao se i broj skladbi hrvatskih skladateljica u udžbenicima za Glazbenu kulturu u osnovnoj školi po razredima. Kao i kod rezultata analize ukupnoga broja skladbi skladateljica, najveći je udio skladbi hrvatskih skladateljica među skladbama koje su 
stvorile skladateljice u drugom razredu osnovne škole. U višim razredima osnovne škole udio djela hrvatskih skladateljica u ukupnom broju skladbi skladateljica je znatno manji u odnosu na niže razrede osnovne škole, a u osmome razredu skladbi hrvatskih skladateljica nema.

Rezultati obiju analiza ukazuju na to da udžbenici za Glazbenu kulturu sadrže veoma mali broj skladbi skladateljica, a da djela hrvatskih skladateljica čine oko $71 \%$ toga broja (udio varira po razredima od $0 \%$ do $100 \%$ ). Jednako tako, iz rezultata iščitavamo da je broj skladbi za slušanje i pjevanje skladateljica uopće pa i hrvatskih skladateljica veći u udžbenicima za Glazbenu kulturu u razredima razredne nastave, nego $\mathrm{u}$ razredima predmetne nastave. Zaključujemo, dakle, da se kontakt s glazbom koju su stvorile skladateljice s godinama školovanja smanjuje te da učenici osnovne škole u nedovoljnoj mjeri upoznaju stvaralaštvo kako domaćih tako i stranih autorica.

\section{Zaključak}

Zahvaljujući nastojanjima muzikološke struke da rasvijetli život i djelo skladateljica čiji je umjetnički rad zbog različitih, ženama nesklonih, društveno-političkih okolnosti tijekom stoljeća bio gotovo nepoznat široj javnosti, potom zahvaljujući djelovanju reproduktivnih umjetnika koji takva djela uvrštavaju u svoj repertoar te zahvaljujući mnoštvu različitih medijskih platformi, suvremeni čovjek u prilici je konzumirati i upoznati stvaralaštvo velikoga broja skladateljica koje već stoljećima stvaraju, najčešće u sjeni svojih muških kolega. Današnja muzikologija reevaluira taj dio zapadno-europske glazbene baštine, smještajući ostvarenja skladateljica uz bok stvaralaštvu etabliranih skladatelja različitih glazbeno-povijesnih epoha. No, promjene koje se događaju u glazbenoj struci ne odražavaju se u dovoljnoj mjeri na glazbeno-pedagošku praksu.

Rezultati analize skladbi za slušanje i pjevanje u udžbenicima za Glazbenu kulturu u osnovnoj školi ukazuju na to da su djela skladateljica i dalje značajno podzastupljena u ukupnom broju skladbi. Dapače, broj djela skladateljica koja učenici imaju priliku upoznati kroz udžbenike za Glazbenu kulturu bitno se smanjuje prelaskom djece iz razredne u predmetnu nastavu. Rezultati analize ukazuju i na to da učenici osnovne škole imaju priliku upoznati mali broj skladbi hrvatskih skla- 
dateljica. Broj djela hrvatskih skladateljica također je manji u udžbenicima za razrede predmetne nastave nego u onima za učenike razredne nastave. Budući da su udžbenici i prateći materijali uz udžbenike najčešce osnova za planiranje i realizaciju nastave Glazbene kulture, možemo zaključiti da učenici tijekom primarnoga obrazovanja upoznaju jako mali broj skladbi skladateljica.

Upravo iz tih razloga potrebno je ustrajati u promoviranju stvaralaštva skladateljica umjetničke, popularne i tradicijske glazbe te skladbi dječje tematike. Također, potrebno je revidirati popise djela za pjevanje i slušanje u udžbenicima za Glazbenu kulturu u korist stvaralaštva skladateljica, što ovisi o prijedlogu popisa u Kurikulumu za nastavni predmet Glazbene kulture za osnovne škole i o samim autorima budućih udžbenika. Tako osviještenim stavom, učenici osnovne škole imali bi priliku, uz najveća ostvarenja skladatelja, upoznati i značajna djela mnogih umjetnički relevantnih autorica s ciljem razvijanja svijesti o tome da glazbeni, kao i svaki drugi talent, nisu uvjetovani spolom.

\section{Literatura}

Ambruš-Kiš, Ružica; Janković, Ana i Mamić, Željkica (2020), Glazbeni krug 1, Zagreb: Profil Klett d.o.o.

Ammer, Christine (2001), Unsung: A History of Women in American Music, century edition, Portland, OR: Amadeus Press.

Atanasov Piljek, Diana (2019), Moja glazba 1, Zagreb: Alfa d.d.

Atanasov Piljek, Diana (2020), Moja glazba 2, Zagreb: Alfa d.d.

Atanasov Piljek, Diana (2020), Moja glazba 3, Zagreb: Alfa d.d.

Banov, Natalija i sur. (2020), Allegro 5, Zagreb: Školska knjiga d.d.

Banov, Natalija i sur. (2020), Allegro 6, Zagreb: Školska knjiga d.d.

Banov, Natalija i sur. (2020), Allegro 7, Zagreb: Školska knjiga d.d.

Bernabé-Villodre, Ma del Mar i Martínez-Bello, Vladimir E. (2018), »Analysis of gender, age and disability representation in music education textbooks: A research update«, International Journal of Music Education, 36(4), str. 494508. https://doi.org/10.1177/0255761418763900

Brlečić, Domagoj, Đonlić, Nera, Jambrošić, Nikola Sebastian i Ostojić, Ana (2019), Svijet glazbe 7, Zagreb: Alfa d.d.

Carper, Kenneth (2001), »The effects of repeated exposure and instructional activities on the least preferred of four culturally diverse musical styles with kindergarten and pre-K children«, Bulletin of the Council for Research in Music Education, 151, str. 41-50. 
Dobrota, Snježana i Ćurković, Gordana (2006), »Glazbene preferencije djece mlađe školske dobi«, Život i škola, 15-16(1-2), str. 105-114.

Dobrota, Snježana i Mikelić, Matija (2012), »Glazbene preferencije učenika prema glazbi različitog tempa«, Metodički ogledi, 19(2), str. 137-146.

Dobrota, Snježana i Conar, Ružica (2018), »Stavovi učenika prema nastavi Glazbene kulture i Glazbene umjetnosti«, Život i škola, 64(1), str. 131-139. https:// doi.org/10.32903/zs.64.1.10

Dobrota, Snježana i Topić, Kristina (2018), »Glazbene preferencije učenika prema glazbama svijeta i hrvatskoj tradicijskoj glazbi«, Školski vjesnik, 67(2), str. 199-209.

Dvořak, Vlasta; Jeličić Špoljar, Margita i Kirchmayer Bilić, Eva (2015), Allegro 4 u glazbenom svijetu, Zagreb: Školska knjiga d.d.

Dvořak, Vlasta; Jeličić Špoljar, Margita i Kirchmayer Bilić, Eva (2015), Allegro 8 u glazbenom svijetu, Zagreb: Školska knjiga d.d.

Gašpardi, Ante; Lazarić, Tonka; Raguž, Nevenka; Ostojić, Ana i Štefanac, Zoran (2019), Svijet glazbe 5, Zagreb: Alfa d. d.

Gašpardi, Ante; Lazarić, Tonka; Raguž, Nevenka i Štefanac Zoran (2018), Svijet glazbe 4, Zagreb: Alfa d.d.

Gates, Eugene (2006), »The woman composer question: Philosophical and historical perspectives«, The Kapralova Society Journal, 4(2), str. 1-11.

Jambrošić, Nikola Sebastian; Ostojić, Ana i Raguž, Nevenka (2019), Svijet glazbe 6, Zagreb: Alfa d.d.

Green, Lucy (1997), Music, Gender, Education, London: Cambridge University Press.

Jandrašek, Vladimir i Ivaci, Jelena (2020), Razigrani zvuci 1, Zagreb: Školska knjiga d.d.

Jandrašek, Vladimir i Ivaci, Jelena (2020), Razigrani zvuci 2, Zagreb: Školska knjiga d.d.

Jandrašek, Vladimir i Ivaci, Jelena (2020), Razigrani zvuci 3, Zagreb: Školska knjiga d.d.

Janković, Ana; Mamić, Željkica i Ambruš-Kiš, Ružica (2020), Glazbeni krug 3, Zagreb: Profil Klett d.o.o.

Janušić, Juliette (2008), »Analiza srednjoškolskih udžbenika za Hrvatski jezik i književnost: primjer rodnog čitanja«, Metodički ogledi, 15(1), str. 61-80.

Knežević, Đurđa (2012), »Femme fatale s petero djece. Analiza osnovnoškolskih udžbenika povijesti iz rodne perspektive«, Politička misao, 49(2), str. 73-96.

Krnić, Marijo i Kodžoman-Radan, Josipa (2015), »Roditelji i dječje glazbene aktivnosti u obiteljskom domu«, Metodički ogledi, 23(1), str. 53-64. https://doi. org/10.21464/mo43.231.5364 
LeBlanc, Albert; Sims, Wendy. L.; Siivola, Carolyn, i Obert, Mary (1996), »Music style preferences of different age listeners«, Journal of Research in Music Education, 44(1), str. 49-59. https://doi.org/10.2307/3345413

Lindeman, Carolynn A. (1992), »Teaching about women musicians: Elementary classroom strategies«, Music Educators Journal, 78(7), str. 56-59. https:// doi.org/10.2307/3398362

Mamić, Željkica; Janković, Ana i Ambruš-Kiš, Ružica (2020), Glazbeni krug 2, Zagreb: Profil Klett d.o.o.

Reitsma, Kimberly (2014), »A new approach: The feminist musicology studies of Susan McClary and Marcia J. Citron. B.A. in Music Senior Capstone Projects. 10.«, digitalcommons.cedarville.edu. Dostupno na: https://digitalcommons.cedarville.edu/music_and_worship_ba_capstone/10 [10.9. 2020.]

Senjan, Saša (2021), »Narodno prosvjećivanje u sjevernoj Hrvatskoj (1945.1952.), doktorska disretacija, Zagreb: Sveučilište u Zagrebu, Filozofski fakultet. Dostupno na: https://urn.nsk.hr/urn:nbn:hr:131:180018 [22. 4. 2021.]

Ščedrov, Ljiljana i Marić, Saša (2012), Glazbena petica, Zagreb: Profil Klett d.o.o.

Ščedrov, Ljiljana i Marić, Saša (2013), Glazbena šestica, Zagreb: Profil Klett d.o.o.

Ščedrov, Ljiljana i Marić, Saša (2019), Glazbena osmica, Zagreb: Profil Klett d.o.o.

Šulentić Begić, Jasna; Begić, Amir i Pušić, Ivana (2020), »Preferencije učenika prema aktivnostima i sadržajima u nastavi Glazbene kulture«, Nova prisutnost, 18(1), str. 185-202. https://doi.org/10.31192/np.18.1.13

Trupković, Željka (2008), »Prikaz žena u udžbenicima povijesti za osnovnu školu iz 1997. i 2007. godine«, Povijest u nastavi, 6(12), str. 177-193.

Zaimont, Judith L. (1987), The Musical Woman, Westport, CT: Greenwood Press. 


\title{
ARTWORK BY FEMALE COMPOSERS IN PRIMARY MUSIC EDUCATION
}

\author{
Marijo Krnić, Ani Silić
}

The female composers'musical pieces are an important but relatively unknown part of the musical and historical heritage. They are also underrepresented in the contemporary musical culture. Children are introduced to works of female composers mainly through the music curriculum in primary schools. This paper presents the research of the Music education textbooks that are in use in primary schools in Croatia. The main aim of the research was to establish the number of compositions by female music composers in the overall number of compositions listed for listening and singing in textbooks, especially the presence of pieces authored by Croatian female composers. We have analyzed 21 textbooks from three Croatian publishing houses. Results show that compositions by male compositors are most often, and then follow traditional compositions, while the compositions of female composers are significantly less present. We propose the revision of the compositions for listening and singing that are included in the Music education textbooks in a way that would enable greater participation of work by both Croatian and other female composers.

Keywords: female composers, Music education, textbooks, compositions for signing and listening 